\title{
X. KRONIKA
}

\section{JUBILEUSZ SZEŚĆDZIESIECCIOLECIA INSTYTUTU HISTORII PRAWA UNIWERSYTETU WARSZAWSKIEGO}

W 2012 r. Instytut Historii Prawa Wydziału Prawa i Administracji Uniwersytetu Warszawskiego obchodził jubileusz sześćdziesięciolecia swego powstania. $Z$ tej okazji 3 grudnia 2012 r. zorganizowano konferencję Historia prawa - nauka teoretyczna czy praktyczna? W jednej z najładniejszych uniwersyteckich sal - Sali Balowej Pałacu Potockich zgromadzili się zaproszeni goście: historycy prawa z całej Polski i gospodarze - pracownicy Instytutu, reprezentujący różne pokolenia i zainteresowania badawcze. Celem spotkania poza uczczeniem Instytutu - Jubilata była dyskusja o zmianach zachodzących $w$ nauce historii prawa i w programach nauczania dyscypliny.

Konferencję otworzyła dyrektor Instytutu profesor Maria Zabłocka. Następnie profesor Grażyna Bałtruszajtys-Piotrowska przypomniała historię pierwszych lat Instytutu, podkreślając na wstępie, że istnieje już kilka publikacji dotyczących jego losów, autorstwa: Juliusza Bardacha, Bogusława Leśnodorskiego, Stanisława Russockiego oraz Wandy Sudnik. Już w czasie II wojny światowej tajna edukacja prawnicza obejmowała, wśród innych dyscyplin, przedmioty prawno-historyczne. Jeden z wykładowców - prof. Józef Rafacz - zginął podczas powstania warszawskiego, rozstrzelany przez Niemców w Domu Profesorów na ul. Brzozowej. Wojnę przeżył natomiast - także zaangażowany w tajne nauczanie historyk prawa - prof. Jakub Sawicki, który od lipca 1945 r. uczestniczył w organizowaniu Wydziału Prawa. Wkrótce też przybył do Warszawy romanista prof. Edward Gintowt. W 1947 r. utworzono Katedrę Papirologii Prawniczej i Praw Antycznych, którą objął prof. Rafał Taubenschlag, skonfliktowany z Edwardem Gintowtem. Konflikt ten był jedną z przyczyn, które spowodowały, że badania papirologiczne zostały przeniesione do Instytutu Historycznego.

9 grudnia 1950 r. odbyło się zebranie, na którym przyjęto statut Instytutu Historii Prawa. W jego skład weszły: zespołowa Katedra Historii Państwa i Prawa Polskiego, z którą związani byli już wówczas: Jakub Sawicki, Juliusz Bardach i Bogusław Leśnodorski, Katedra Powszechnej Historii Państwa i Prawa (prof. Karol Koranyi), Katedra Prawa Rzymskiego (prof. Edward Gintowt), Katedra Państwowego Prawa Wyznaniowego (prof. Henryk Świątkowski) oraz badawcza Katedra Historii Porów- 
nawczej Prawodawstw Słowiańskich, która pozostawała nieobsadzona aź do roku 1958, kiedy objął ją prof. Władysław Sobociński. Od czasu likwidacji Katedry Państwowego Prawa Wyznaniowego w 1952 r. Instytut prowadził wyłącznie badania prawno-historyczne.

Kolejne wystąpienia dotyczyły już współczesnych problemów dyscypliny. Profesor Marek Wąsowicz przypomniał, że w dociekaniach prawnika zasadniczo dominuje postawa postulująca: jak powinno być, jak należy interpretować prawo? Historyk natomiast zajmuje się wyjaśnieniem opisywanych zagadnień. Następnie referent odniósł się do aktualnej tendencji do czynienia $\mathrm{z}$ historii prawa dyscypliny całkowicie utylitarnej, służącej praktyce prawniczej. Najpierw pojawiła się ona w dydaktyce przedmiotów prawno-historycznych, a następnie zaczęła również wywierać wpływ na badania, prowadząc do sytuacji, w której dogmatycy zaczynają narzucać historykom prawa listę zagadnień wartych analizowania. Taka tendencja może jednak uczynić z historii prawa dyscyplinę wtórną, czego konsekwencją będzie zanik jej tożsamości oraz upadek warsztatu badawczego. Pierwsze symptomy tego możemy już obserwować.

Profesor Wacław Uruszczak w swoim wystąpieniu wskazał na kilka przypadków zastosowania wiedzy prawno-historycznej we współczesnej praktyce sądowej. Zrelacjonował sprawę, w której - wbrew zasadzie iura novit curia - został powołany $\mathrm{w}$ charakterze biegłego $\mathrm{w}$ celu ustalenia stanu prawnego jednego $\mathrm{z}$ małopolskich lasów. Kazimierz Wielki nadał bowiem parafii w Niepołomicach prawo wyrębu drewna w królewskim lesie. Gdy współczesny proboszcz chciał z tego prawa korzystać sprzeciwiło się temu kierownictwo Nadleśnictwa Niepołomice. Po przeanalizowaniu sprawy prof. Uruszczak wykazał, że prawo wyrębu przekształciło się w ciężar realny, a więc - zgodnie z ustawą Przepisy wprowadzające kodeks cywilny obowiązuje do dziś.

W innej sprawie prof. Uruszczak, jako pełnomocnik jednej ze stron, wykazał, że w świetle prawa austriackiego nie było możliwe w drodze umowy utworzenie służebności drogi koniecznej - była do tego niezbędna decyzja administracyjna. A zatem umowa, na którą powoływała się strona przeciwna nie ma doniosłości prawnej. Prelegent przypomniał też o zaangażowaniu Oswalda Balzera w spór graniczny pomiędzy Królestwem Galicji i Lodomerii a Królestwem Węgier. Wywody wybitnego uczonego przed sądem polubownym w Grazu, podbudowane solidną erudycją i badaniami źródłowym pozwoliły na zachowanie przy Galicji tej części Tatr Wysokich, która należała przed rozbiorami do Rzeczypospolitej i dzięki temu do dziś popularne górskie jezioro Morskie Oko pozostaje w jej granicach.

Podsumowanie swego wystąpienia prof. Uruszczak poświęcił wadze dydaktyki przedmiotów prawno-historycznych. Stwierdził, ze przyszłym polskim elitom potrzebna jest wiedza o przeszłości prawnej i ustrojowej własnego państwa. Niezwykle istotne jest również, aby adepci nauk prawnych zdawali sobie sprawę z tego, że prawo to nie tylko same przepisy, ale pewna całość, na którą składają się akty normatywne, orzecznictwo, doktryna oraz - jak to ujął Ronald Dworkin - zasady i reguły. Trzeba, aby mieli dystans do przepisów i ich nie absolutyzowali. Takie postawy, taką wiedzę winna dawać edukacja historyczno-prawna. 
Profesor Wojciech Witkowski w swoim wystąpieniu ukazal postrzeganie historii prawa przez minione 200 lat. Przypomniał, że Romuald Hube i Karol August Heylman, którzy jako jedni z pierwszych podjęli refleksję nad zagadnieniami metodologicznymi historii prawa, uważali, że jest ona nauką teoretyczną. Pierwszy z nich pisał na łamach Themis Polskiej, że: ,historia [...] uczy nas dlaczego prawa tak a nie inaczej rozwijały się, i jak dalece instytucje prawne połączone są z duchem, charakterem, moralnością narodu. Przez historię przychodzimy do poznania stanu obecnego, za pomocą rozważania wieków upłynionych; na tej drodze poznanie teraźniejszości przybiera pewną nieomylność, upoważniając nas nawet do czynienia wniosków, w przyszłości nawet znaczenie mieć mogących".

Zaś w latach dwudziestych XX w. Eugeniusz Jarra pisał: „Nauki prawne mając za przedmiot życie społeczne są naukami par excellence historycznymi i dopiero od czasów kiedy do nich tę zastosowano właśnie metodę, kwestia powstania i rozwoju prawa zyskała właściwy punkt widzenia a instytucje współczesne - klucz do ich zrozumienia".

Metoda historyczna jest niezwykle ważna w prawoznawstwie, wyjaśnia przyczyny, które spowodowały wykształcenie się poszczególnych instytucji prawnych. Traktował zatem Jarra historię prawa jako dyscyplinę pomocniczą nauk prawnych. Z kolei po II wojnie światowej Jerzy Lande historię prawa potraktował jako naukę teoretyczną. Uznał, że może ona mieć wyłącznie funkcję informacyjną - jako źródło przykładów, które posłużą do uogólnień przy tworzeniu ogólnej teorii prawa.

Kolejna część spotkania poświęcona była dyskusji, którą prowadził prof. Marek Wąsowicz. Prof. Witold Wołodkiewicz stwierdził, że przedmioty historyczne mają w wykształceniu młodych prawników walor przedmiotów formujących, które dadzą im odpowiednią perspektywę $\mathrm{W}$ patrzeniu na współczesne, ciągle zmieniające się prawo. Prof. Tomasz Giaro przedstawił własny punkt widzenia i argumentował, że historycy prawa powinni przede wszystkim wykazywać, iż są potrzebni dogmatykom i pokazywać im, że ich problemy wynikają często z nieznajomości historii. Do tego niezbędna jest znajomość prawa współczesnego.

$Z$ poglądem tym polemizowała doc. dr Anna Rosner, która uznała, że od podejmowania tematów aktualnych, co rodzi ryzyko prezentyzmu, ważniejsze jest udowadnianie, że historia prawa jest przydatna dydaktycznie i może służyć przekazywaniu wartości oraz ćwiczeniom metodologicznym. Natomiast nauka powinna być uprawiana niezależnie od doraźnych, koniunkturalnych względów. Opinię tę poparł prof. Aleksander Stępkowski, który stwierdził, iż nazbyt usilne próby udowadniania dogmatykom tego, że historia prawa jest współcześnie doniosła, rodzi ryzyko, że przedstawiciele tej dyscypliny staną się zbieraczami ciekawostek. Natomiast prof. Dorota Malec stwierdziła, że nie należy zbyt ściśle łączyć badań z dydaktyką przedmiotów prawno-historycznych, o których wadze należy przekonać nie tylko uniwersyteckich i wydziałowych decydentów, ale i samych studentów. Z kolei prof. Michał Pietrzak ocenił, że każdy historyk prawa powinien oprócz przedmiotu historycznego wykładać jakiś przedmiot dogmatyczny. Także prof. Ryszard Łaszewski uznał, że historycy prawa są przede wszystkim prawnikami, a wielu z nich łączy pracę naukową z praktyką prawniczą. 
Obrady podsumował prof. Marek Wąsowicz. Zauważył, że w środowisku historyczno-prawnym panuje zgoda co do potrzeby prowadzenia dydaktyki w dotychczasowym rozmiarze, istnieją natomiast rozbieżności w kwestiach metodycznych. Przypomniał, że publikacje z zakresu historii prawa są czytane nie tylko przez prawników-dogmatyków, ale i przez przedstawicieli wielu innych dziedzin, oraz wyraził nadzieję, że każde badanie historyczne może - nawet w sposób niespodziewany dla autora - okazać się współcześnie przydatne.

Jubileuszowa sesja Instytutu Historii Prawa UW stała się okazją do wymiany poglądów i doświadczeń tyczących roli historii prawa jako dyscypliny naukowej i jej miejsca w dydaktyce studiów prawniczych. Dobrze się stało, że po raz kolejny w swej sześćdziesięcioletniej historii Instytut mógł takiej dyskusji patronować. Miejmy też nadzieję, że stanie się ona asumptem do dalszych rozważań, łączących harmonijnie naukę i dydaktykę historii prawa.

PIOTR POMIANOWSKI (Warszawa)

\section{MIĘDZYNARODOWA NAGRODA NAUKOWA IM. JULIUSZA BARDACHA}

Instytut Wielkiego Księstwa Litewskiego (IWKL), usytuowany przy Uniwersytecie im. Witolda Wielkiego w Kownie, mający charakter międzynarodowy, ustanowił nagrodę im. Prof. Juliusza Bardacha, wybitnego polskiego historyka prawa, uznanego w świecie lituanisty, doktora honoris causa m.in. Uniwersytetu Wileńskiego.

Nagroda - wedle ogłoszonego regulaminu - przyznawana będzie (od jej pierwszej edycji w 2013 r.) za prace doktorskie i magisterskie (lub równoważne), w których ujęto badania nad polityczno-ustrojowym, prawnym i kulturowym dziedzictwem Wielkiego Księstwa Litewskiego, przejawami tradycji Wielkiego Księstwa Litewskiego w XIX i XX w. bądź podjęto tematy współczesne: władzy i polityki na terytoriach byłego Wielkiego Księstwa - Białorusi, Litwy, Ukrainy oraz Polski w historycznym kontekście. Prace mogą obejmować różne sfery nauk humanistycznych, więc obok historii oraz historii ustroju i prawa, także politologię, filologię, socjologię i geografię.

Instytut Wielkiego Księstwa Litewskiego - firmujący nagrodę im. Juliusza Bardacha - został powołany 26 listopada 2009 r. z udziałem osób prawnych (instytucji państwowych i organizacji pozarządowych) oraz osób fizycznych - wybitnych przedstawicieli nauki i życia społecznego z Litwy, Białorusi, Ukrainy i Polski.

Do założycieli IWKL - osób prawnych należą: Uniwersytet Witolda Wielkiego w Kownie (UWW) oraz „Czesław Miłosz Birthplace Foundation” (Šeteniai /Kedainiai/ - Kaunas) - fundacja z siedzibą w Kownie i w Szetejniach (d. powiat kiejdański), więc w miejscu urodzenia Patrona. Jest tu też fundacja „Sigugara” (Kaunas).

Do założycieli indywidualnych - partnerów Instytutu zaliczają się znani, wybitni badacze litewscy: prof. Egidijus Aleksandravičius, dyrektor Instytutu Litewskiej 